http://dx.doi.org/10.11646/zootaxa.3838.3.8

http://zoobank.org/urn:lsid:zoobank.org:pub:7431AB99-1BE8-4A81-97F0-CC341730FEDF

\title{
An unusual new fossil genus probably belonging to the Psychopsidae (Neuroptera) from the Eocene Okanagan Highlands, western North America
}

\author{
VLADIMIR N. MAKARKIN ${ }^{1,3} \&$ S. BRUCE ARCHIBALD ${ }^{2}$ \\ ${ }^{1}$ Institute of Biology and Soil Sciences, Far Eastern Branch of the Russian Academy of Sciences, Vladivostok 690022, Russia \\ ${ }^{2}$ Department of Biological Sciences, Simon Fraser University, 8888 University Drive, Burnaby, BC, Canada V5A IS6 \\ ${ }^{3}$ Corresponding author.E-mail: vnmakarkin@mail.ru
}

\begin{abstract}
The new genus and species Ainigmapsychops inexspectatus gen. et sp. nov. is described from the early Eocene Okanagan Highlands locality at Republic, Washington, U.S.A. We preliminarily assign it to the Psychopsidae; however, its venation is unusual within this family, particularly by its pectinate branches of AA1 originating at a steep angle, a character state more suggestive of the Osmylidae.
\end{abstract}

Key words: Neuroptera, Psychopsidae, Osmylidae, Okanagan Highlands

\section{Introduction}

A rich assemblage of fossil Neuroptera has been reported in the last several decades from early Eocene Okanagan Highlands lacustrine shales, recovered from depositional basins scattered across about a thousand kilometers of southern British Columbia, Canada, into Washington State, U.S.A. (Archibald et al. 2011). These include 26 described species, 18 named and a further 8 unnamed, belonging to a diverse suite of families: Ithonidae (including Polystoechotidae), Chrysopidae, Hemerobiidae, Nymphidae and Berothidae (Makarkin \& Archibald 2003, 2009, 2013; Makarkin et al. 2003; Archibald \& Makarkin 2004, 2006; Archibald et al. 2009). We have examined about 120 Neuroptera specimens, many preserved in very fine levels of detail. Undescribed material amongst these includes new taxa of Osmylidae and Hemerobiidae, more Chrysopidae, and many more specimens of Ithonidae (Archibald \& Makarkin, pers. obs.). New material emerges every field season; the Okanagan Highlands continues to reveal an increasingly important assemblage for understanding the evolution of the order in the Eocene, a critical time in the development of its modern nature.

The single Okanagan Highlands species ascribed to the silky lacewing family, Psychopsidae, was later shown to be an ithonid (Andersen 2001; later assigned to the Polystoechotidae by Makarkin \& Archibald 2003, a family that was subsequently synonymized with Ithonidae by Winterton \& Makarkin 2010). Here, we describe an enigmatic new neuropteran genus and species from the Okanagan Highlands locality at Republic, Washington, U. S. A., that we preliminarily assign to the family Psychopsidae - preliminarily, as its venation is very unusual within it.

Today, the Psychopsidae is composed of only 27 species, distributed in southern to central Africa, Southeastern Asia, and Australia (Tjeder 1960; New 1989; Oswald 1993b, 1994; Wang \& Bao 2006). Their Mesozoic fossil record is rich (see a list of described species in Peng et al. 2011), but remains poorly resolved taxonomically. The oldest fossil placed in the family is the Late Triassic Triassopsychops superbus Tillyard, 1922 from Australia. Psychopsid fossils are rare in the Cenozoic; only five species in two genera have been described, all from the brief late Eocene-early Oligocene interval: Propsychopsis Krüger, 1923 from late Eocene Baltic amber (P. helmi Krüger, 1923; P. hageni MacLeod, 1971; P. lapicidae MacLeod, 1971) and Miopsychopsis Makarkin, 1991 from the late Eocene/early Oligocene (age after Archibald et al. 2005) locality at Amgu, in the Russian Far East (M. relicta Makarkin, 1991; M. sikhotensis Makarkin, 1991). While the forewing of Propsychopsis is typical for modern psychopsids, the rather unusual wing morphology of the younger Miopsychopsis species indicates a more distant relationship with extant members of the family. 
The new species is then of considerable interest, not only for expanding knowledge of the diversity of Neuroptera in the Okanagan Highlands, but, more broadly, in shedding light on the early Paleogene history of Psychopsidae, and generally psychopsid-like Neuroptera, and adding to larger patterns of the emergent modern character of Neuroptera early in the Cenozoic.

\section{Material and methods}

This work is based on a specimen from exposure A0307 of the Klondike Mountain Formation, which was deposited in and regionally around the town of Republic, Ferry County, north-central Washington (although somewhat outdated now, see the review in the Republic Centenary issue of Washington Geology: Reed 1996). Its fossil-bearing shale is estimated to be latest Ypresian, $49.4 \pm 0.5 \mathrm{Ma}$ (Wolf et al. 2003) by radiometric dating. Paleobotanical analyses indicate that the climate was temperate, with an upper microthermal MAT (mean annual temperature); estimates range from $\sim 9-13^{\circ} \mathrm{C}$ and few, if any frost days (Greenwood et al. 2005). The Republic forest was similar to that of the modern North American eastern deciduous zone, but included elements that are today restricted to lower latitudes (such as palms), range in East Asia (such as Metasequoia, Ginkgo, etc.) or are extinct (Greenwood et al. 2005, Moss et al. 2005). Insects and other fossils (plants, fish, more rarely feathers) have been recovered from various outcrops of this formation in the region of Republic, but the great majority of fossils are from A0307 and B4131, close to each other within the town proper.

We use the venational terminology of Yang et al. (2012), except in the case of the anal veins, where we in general follow that applied to other Neoptera by some authors (e.g., Béthoux 2005; Béthoux \& Jarzembowski 2010), i.e., all anal veins are branches of anterior analis (AA). Furthermore, terminology of wing spaces, crossveins, and veinlets follows Oswald (1993a).

\section{Systematic paleontology}

\section{Insecta Linnaeus, 1758}

\section{Neuroptera Linnaeus, 1758}

\section{Family Psychopsidae Handlirsch, 1906}

\section{Genus Ainigmapsychops gen. nov.}

Type and only species. Ainigmapsychops inexspectatus sp. nov.

Diagnosis. Forewing easily separated from those of other species of Psychopsidae by a combination of the following character states: (1) costal space broad proximally, strongly narrowed toward apex [shared with many Mesozoic genera; equally broad in all extant and fossil Cenozoic genera]; (2) costal crossveins absent in preserved portion of costal space [shared with few Mesozoic genera; at least few (often many) crossveins present in all extant and Cenozoic genera]; (3) branches of RP simple before outer gradate series of crossveins [shared with all extant and Cenozoic genera; dichotomously branched in many Mesozoic genera]; (4) CuA strongly pectinate, with numerous branches [dichotomous (or so) or pectinate with few branches in most Mesozoic genera]; (5) CuP pectinate, with few branches [shared with some Mesozoic genera; strongly pectinate with numerous branches in extant genera]; (6) branches of CuA, CuP short [relatively long in Mesozoic genera]; (7) cubital/anal area relatively narrow [shared with all extant genera; broad in Mesozoic genera]; (8) branches of AA1 running at steep angle [low angle in all other genera].

Etymology. Ainigma- (from Greek ainigma, riddle, enigma) + -psychops (a traditional ending of psychopsidlike genera, from Psychopsis, a genus-group name), in reference to the unusual wing venation of the genus. Gender masculine. 

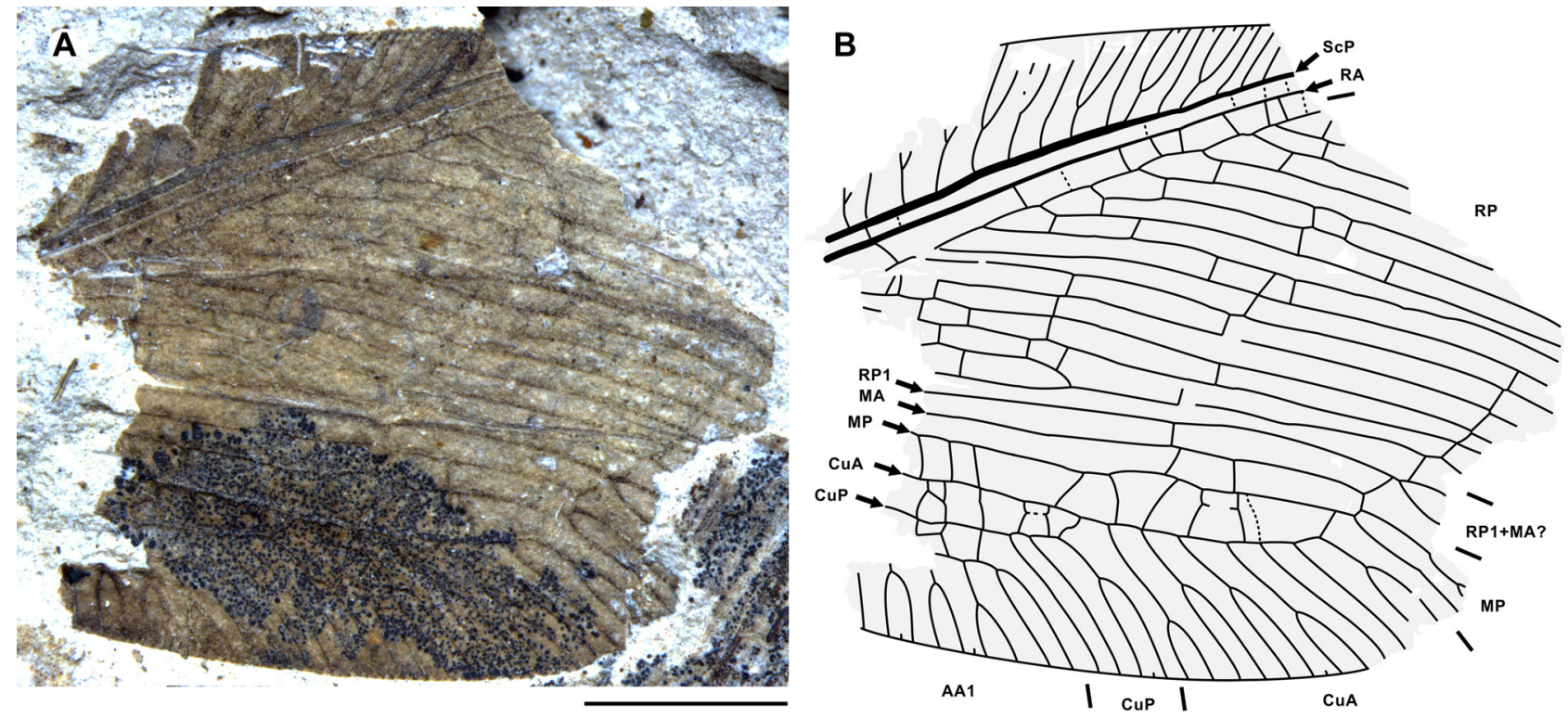

FIGURE 1. Ainigmapsychops inexspectatus gen et sp. nov., holotype SRUI 99-96-76. A, specimen as preserved; B, forewing venation. Scale bar $=2 \mathrm{~mm}$.

\section{Ainigmapsychops inexspectatus sp. nov.}

(Fig. 1)

Description. Forewing $7.2 \mathrm{~mm}$ long as preserved (estimated complete length ca. $15 \mathrm{~mm}$ ), $6.5 \mathrm{~mm}$ wide. Costal space very broad medially and probably basally, strongly narrowed toward apex. Most preserved subcostal veinlets deeply forked, others simple. No costal crossveins. ScP stout, especially proximally. Subcostal space moderately narrow, with weakly-developed crossveins (six detected, but possibly more present). RA space narrow, only slightly wider than subcostal space, with crossveins irregularly spaced (ten detected, possibly more present). RP nearly smooth, with 15 preserved branches. RP2, RP3 fused at level of termination of AA1. Preserved branches of RP not forked before outer gradate series. Radial crossveins numerous, mostly arranged in four gradate series, but proximal crossveins mainly spaced irregularly; first gradate series running close to RP stem; second series irregular, short, located distad proximal crossveins; third (intermediate) series strongly irregular, occupying central wing area; fourth (outer) series regular. Fork of M not preserved. MA incomplete, probably fused with RP1 at outer gradate series (or terminating on RP1). MP deeply forked at outer gradate series. Intramedial crossveins rare, two detected. Mediocubital space (between MP, CuA) broad, with many irregularly spaced crossveins (all curved or oblique; two crossveins connected by additional crossvein). CuA markedly convex, quite deeply forked distally, pectinately branched with six branches (four rather deeply forked, two simple). CuP running parallel to hind margin, deeply forked distally, pectinately branched with two simple branches. Mediocubital, intracubital and cubitoanal spaces with many irregularly spaced crossveins (all curved or oblique; four pairs of crossveins connected by additional crossveins). AA1 long, running parallel to hind margin, pectinately branched with four preserved branches (three deeply forked, one simple, one incomplete). No crossveins between branches of AA1. Wing membrane appears more or less one-colored, dark, here preserved as brownish.

Material. Holotype SRUI 99-96-76 (part only), collected by Gregg Wilson on April 28, 2013. A rather wellpreserved central part of a forewing, housed in the collection of the Stonerose Interpretive Center, Republic, Washington, U.S.A.

Type locality and horizon. Tom Thumb Tuff Member of the Klondike Mountain Formation, exposure A0307, Republic, Washington, U.S.A.; early Eocene (Ypresian).

Etymology. From the Latin inexspectatus $[-a,-u m]$, unexpected, in reference to the surprise of finding this odd wing. 


\section{Family affinity of Ainigmapsychops gen. nov.}

The holotype and only known forewing specimen of A. inexspectatus is largely complete and clearly preserved, however, it lacks portions of the base and apex that bear important family-level diagnostic characters, leaving some doubt as to its family affinity. Its preserved venation shows similarities with both the Osmylidae and the Psychopsidae, although it would be odd within either.

Osmylidae. Of the five families of the osmyloid clade (Osmylidae, Archeosmylidae, Panfiloviidae, Grammolingiidae and Saucrosmylidae; Makarkin et al. 2013: Fig. 7), only Osmylidae appears comparable with this genus, the others are very dissimilar. The venation of the posterior part of the Ainigmapsychops forewing is most similar to that of Osmylidae in the distinctively rather steep angle of branches of CuA, CuP and AA1 relative to the main veins anteriad these and to the wing margin. The following, however, argue against an osmylid affinity.

Ainigmapsychops has few pectinate branches of CuP. The only osmylids that have a $\mathrm{CuP}$ with so few branches (most pectinate, some dichotomous) are some Jurassic species (e.g., see Mesosmylina mongolica Ponomarenko, 1984: Fig. 1; Juraheterosmylus antiquatus Wang et al., 2010: Fig. 2; Epiosmylus panfilovi Ren et Yin, 2002: Fig. 3; Jurakempynus sinensis Wang et al., 2011: Fig. 2B; Archaeosmylidia fusca Makarkin et al. 2014: Fig. 1). In all of these cases, however, the wings differ from that of Ainigmapsychops in many other, significant ways, indicating that this similarity is superficial, convergent. In all other known Cretaceous, Cenozoic and extant species of Osmylidae, CuP has numerous pectinate branches.

The costal space of Ainigmapsychops is strongly dilated proximally, with widely spaced subcostal veinlets, most of which are deeply forked. This is never known to occur in the Osmylidae.

Other venation of Mesozoic Osmylidae is conservative, close to that of extant species; even the most differing, undescribed osmylids from the Middle Jurassic of Daohugou, China, with extreme amounts of crossvenation, are fundamentally similar to modern and to other fossil members of the family (V.M., pers. obs.), differing strongly from Ainigmapsychops.

All osmylids from the Okanagan Highlands (numerous undescribed species) have venation (including in the costal space) typical for the family, also very dissimilar to that of Ainigmapsychops. Other Cenozoic records of Osmylidae from the Eocene Fur Formation (Denmark), Baltic amber, Florissant (U.S.A.), and Redbank Plains Series (Australia), and Miocene of Daia-Săsească [=Thalheim], Romania (Andrae 1855; Pictet-Baraban \& Hagen 1856; Carpenter 1943; Lambkin 1987; Rust 1999; Wichard et al. 2009) all belong to extant families of Osmylidae, and bear venation strongly dissimilar to Ainigmapsychops.

An osmylid affinity of Ainigmapsychops is unlikely.

Psychopsidae. The venation of Psychopsidae is much more diverse. Many Mesozoic genera assigned to the family are strongly dissimilar to modern members; many are poorly defined and might not even belong to the family (see Jepson et al. 2009). These may belong to the poorly defined Osmylopsychopidae or Brongniartiellidae, which are also very diverse, some of which can hardly be distinguished from some Mesozoic Psychopsidae if the wing is incomplete.

Jepson et al. (2009) characterized the psychopsid wing by a combination of:

(A) the costal space very broad throughout (width in "pterostigmal region" more than twice the combined width of the adjacent subcostal and RA spaces);

(B) the subcostal space with more than four crossveins (usually more than ten);

(C) RA with few branches distally (if any), usually not pectinate;

(D) crossveins in the radial space usually arranged in two or three series;

(E) $\mathrm{CuA}$ and $\mathrm{CuP}$ pectinately branched in most species.

States (B), (D), and (E) are present in Ainigmapsychops, and state (C) is not available as preserved; only state (A) confidently differs.

Indeed, for (A), the costal space in all extant and Cenozoic Psychopsidae is equally very broad for its entire length. However, the strongly narrowed costal space towards the wing apex as found in Ainigmapsychops occurs in many (if not most) Mesozoic psychopsids, in particular in all Late Cretaceous genera (e.g., an unnamed genus and species from the Turonian New Jersey amber: Grimaldi 2000: Fig. 4).

The major similarity shared by Ainigmapsychops and the Osmylidae is the distinctively steep angle of branches of $\mathrm{CuA}, \mathrm{CuP}$ and AA1. This angle is low in almost all Mesozoic Psychopsidae (and Osmylopsychopidae and Brongniartiellidae). In extant species, however, the pectinate branches of $\mathrm{CuA}$ and $\mathrm{CuP}$ run at a relatively steep 
angle as well, similar to the condition seen in Ainigmapsychops (e.g., Psychopsis mimica Newman, 1842: New 1989: Fig. 43; P. barnardi Tillyard, 1925: Oswald 1993b: Fig. 32). In the Baltic amber Propsychopsis, the single fossil Cenozoic psychopsoid genus represented by specimens where the cubical and anal veins are preserved, this angle is slightly lower than in most extant species.

Also noteworthy, the relatively narrow cubital/anal area as found in this genus is characteristic of all extant genera of Psychopsidae and the Baltic amber Propsychopsis.

The costal space in most psychopsid species possesses crossveins connecting subcostal veinlets, contrary to Ainigmapsychops. However, the absence of costal crossveins is found in some Mesozoic genera similar to Purbepsychopsis parallela Jepson et al., 2012 (Fig. 8) and Undulopsychopsis alexi Peng et al., 2011 (Fig. 3; three crossveins are present only very proximally).

Thus, of the three character states in the Ainigmapsychops diagnosis distinguishing it from all Cenozoic and extant psychopsids (above), states (1) and (2) occur in some genera of the Mesozoic psychopsids. Other conditions are present either in extant (states 3,4,6,7) or Mesozoic taxa (state 5). The branching mode of AA1 is the only state not yet found in this family.

For a more confident family determination of this genus we ideally need the basal and apical portions of both the forewing and the hind wing. Here, we attribute it to the Psychopsidae by the venation available on its single known fossil, which makes a better fit with this family than any other. Our placement, however, is preliminary; Ainigmapsychops possesses venation that is unusual for the Psychopsidae.

\section{Acknowledgements}

We thank Gregg Wilson for donation of this specimen to the Stonerose Interpretive Center; Michael Sternberg, acting Stonerose director, for loan of it to us. S.B.A. thanks Rolf Mathewes (Simon Fraser University, Burnaby, British Columbia) and David Greenwood (Brandon University, Brandon, Manitoba) for lab and fieldwork funding. The study is partly supported by a President's Grant for Government Support of the Leading Scientific Schools of the Russian Federation No.HIII-150.2014.4, and the grant of the Far Eastern Branch of the Russian Academy of Sciences No. 12-I-II30-03 for V.M.

\section{References}

Andersen, S. (2001) Silky lacewings (Neuroptera: Psychopsidae) from the Eocene-Paleocene transition of Denmark with a review of the fossil record and comments on phylogeny and zoogeography. Insect Systematics \& Evolution, 32, 419-438. http://dx.doi.org/10.1163/187631201x00290

Andrae, K.J. (1855) Beiträge zur Kenntniss der fossilen Flora Siebenbürgens und des Banates. Abhandlungen der KaiserlichKöniglichen Geologischen Reichsanstalt, 2 (3/4), 1-48, 12 pls.

Archibald, S.B., Greenwood, D.R., Smith, R.Y., Mathewes, R.W. \& Basinger, J.F. (2011) Great Canadian Lagerstätten. 1. Early Eocene Lagerstätten of the Okanagan Highlands (British Columbia and Washington State). Geoscience Canada, 38 (4), $145-154$.

Archibald, S.B. \& Makarkin, V.N. (2004) A new genus of minute Berothidae (Neuroptera) from Early Eocene amber of British Columbia, Canada. Canadian Entomologist, 136, 59-74. http://dx.doi.org/10.4039/n03-043

Archibald, S.B. \& Makarkin, V.N. (2006) Tertiary giant lacewings (Neuroptera: Polystoechotidae): revision and description of new taxa from western North America and Denmark. Journal of Systematic Palaeontology, 4, 119-155, 307 [errata]. http://dx.doi.org/10.1017/S1477201906001817

Archibald, S.B., Makarkin, V.N. \& Ansorge, J. (2009) New fossil species of Nymphidae (Neuroptera) from the Eocene of North America and Europe. Zootaxa, 2157, 59-68.

Archibald, S.B., Rasnitsyn, A.P. \& Akhmetiev, M.A. (2005) The ecology and distribution of Cenozoic Eomeropidae (Mecoptera), and a new species of Eomerope Cockerell from the Early Eocene McAbee locality, British Columbia, Canada. Annals of the Entomological Society of America, 98, 503-514. http://dx.doi.org/10.1603/0013-8746(2005)098[0503:EADOCE]2.0.co;2

Béthoux, O. (2005) Wing venation pattern of Plecoptera (Insecta: Neoptera). Illiesia, 1(9), 52-81. Available from: http:// www2.pms-lj.si/illiesia/papers/Illiesia01-09.pdf (accessed 30 June 2014)

Béthoux, O. \& Jarzembowski, E.A. (2010) New basal neopterans from Writhlington (UK, Pennsylvanian). Alavesia, 3, 87-96.

Carpenter, F.M. (1943) Osmylidae of the Florissant shales, Colorado (Insecta-Neuroptera). American Journal of Science, 241, 
753-760.

Engel, M.S. \& Grimaldi, D.A. (2008) Diverse Neuropterida in Cretaceous amber, with particular reference to the paleofauna of Myanmar (Insecta). Nova Supplementa Entomologica, 20, 1-86.

Greenwood, D.R., Archibald, S.B., Mathewes, R.W. \& Moss, P.T. (2005) Fossil biotas from the Okanagan Highlands, southern British Columbia and northeastern Washington State: climates and ecosystems across an Eocene landscape. Canadian Journal of Earth Sciences, 42, 167-185.

Grimaldi, D.A. (2000) A diverse fauna of Neuropterodea in amber from the Cretaceous of New Jersey. In: Grimaldi, D.A. (Ed.), Studies on fossil in amber, with particular reference to the Cretaceous of New Jersey. Backhuys Publishers, Leiden, pp. 259-303.

Handlirsch, A. (1906-1908) Die fossilen Insekten und die Phylogenie der rezenten Formen. Ein Handbuch für Palaeontologen und Zoologen. W. Engelmann, Leipzig, ix + 1430 pp. [issued in 1906 (pp. 1-640); 1907 (pp.641-1140); 1908 (pp. 1120-1430)]

Jepson, J.E., Makarkin, V.N. \& Coram, R.A. (2012) Lacewings (Insecta: Neuroptera) from the Lower Cretaceous Purbeck Limestone Group of southern England. Cretaceous Research, 34, 31-47. http://dx.doi.org/10.1016/j.cretres.2011.10.001

Jepson, J.E., Makarkin, V.N. \& Jarzembowski, E.A. (2009) New lacewings (Insecta: Neuroptera) from the Lower Cretaceous Wealden Supergroup of southern England. Cretaceous Research, 30, 1325-1338. http://dx.doi.org/10.1016/j.cretres.2009.07.012

Krüger, L. (1923) Neuroptera succinica baltica. Die im baltischen Bernstein eingeschlossenen Neuroptera des Westpreussischen Provinzial-Museums (heute Museum für Naturkunde und Vorgeschichte) in Danzig. Stettiner Entomologische Zeitung, 84, 68-92.

Lambkin, K.J. (1987) A re-examination of Euporismites balli Tillyard from the Palaeocene of Queensland (Neuroptera: Osmylidae: Kempyninae). Neuroptera International, 4 (4), 295-300.

Linnaeus, C. (1758) Systema naturae per regna tria naturae secundum classes, ordines, genera, species, cum characteribus, differentiis, synonymis, locis, 10th ed. Vol. 1. Salvii, Holmiae, $824 \mathrm{pp}$.

MacLeod, E.G. (1971) The Neuroptera of the Baltic Amber. I. Ascalaphidae, Nymphidae, and Psychopsidae. Psyche, 77 (for 1970), 147-180. http://dx.doi.org/10.1155/1970/45459

Makarkin, V.N. (1991) Miotsenovye setchatokrylye (Neuroptera) Severnogo Kavkaza i Sikhote-Alinya [Miocene Neuroptera from North Caucasus and Sikhote-Alin']. Paleontologicheskii Zhurnal, 1991 (1), 57-68. [in Russian, English summary]

Makarkin, V.N. \& Archibald, S.B. (2003) Family affinity of the genus Palaeopsychops Andersen with description of a new species from Early Eocene of British Columbia (Neuroptera: Polystoechotidae). Annals of the Entomological Society of America, 96, 171-180. http://dx.doi.org/10.1603/0013-8746(2003)096[0171:FAOTGP]2.0.CO;2

Makarkin, V.N. \& Archibald, S.B. (2009) A new genus and first Cenozoic fossil record of moth lacewings (Neuroptera: Ithonidae) from the Early Eocene of North America. Zootaxa, 2063, 55-63.

Makarkin, V.N. \& Archibald, S.B. (2013) A diverse new assemblage of green lacewings (Insecta: Neuroptera: Chrysopidae) from the Early Eocene Okanagan Highlands, western North America. Journal of Paleontology, 87, 122-145. http://dx.doi.org/10.1666/12-052R.1

Makarkin, V.N., Archibald, S.B. \& Oswald, J.D. (2003) New Early Eocene brown lacewings (Neuroptera: Hemerobiidae) from western North America. Canadian Entomologist, 135, 637-653. http://dx.doi.org/10.4039/n02-122

Makarkin, V.N., Yang, Q. \& Ren, D. (2014) A new basal osmylid neuropteran insect from the Middle Jurassic of China linking Osmylidae to the Permian-Triassic Archeosmylidae. Acta Palaeontologica Polonica, 59, 509-514. http://dx.doi.org/10.4202/app.2011.0018

Makarkin, V.N., Yang, Q., Shi, C.F. \& Ren, D. (2013) The presence of the recurrent veinlet in the Middle Jurassic Nymphidae (Neuroptera) from China: a unique condition in Myrmeleontoidea. ZooKeys, 325, 1-20. http://dx.doi.org/10.3897/zookeys.325.5453

Moss, P.T., Greenwood, D.R. \& Archibald, S.B. (2005) Regional and local vegetation community dynamics of the Eocene Okanagan Highlands (British Columbia - Washington State) from palynology. Canadian Journal of Earth Sciences, 42, 187-204.

New, T.R. (1989) The Psychopsidae (Insecta: Neuroptera) of Australia and the Oriental Region. Invertebrate Taxonomy, 2 (for 1988), 841-883.

Newman, E. (1842) Entomological Notes. Entomologist, 1842, 413-415.

Oswald, J.D. (1993a) Revision and cladistic analysis of the world genera of the family Hemerobiidae (Insecta: Neuroptera). Journal of the New York Entomological Society, 101, 143-299.

Oswald, J.D. (1993b) Phylogeny, taxonomy, and biogeography of extant silky lacewings (Insecta: Neuroptera: Psychopsidae). Memoirs of the American Entomological Society, 40, iii+1-65.

Oswald, J.D. (1994) Revision of the African silky lacewing genus Zygophlebius Navás (Neuroptera: Psychopsidae). African Entomology, 2, 83-96.

Peng, Y.Y., Makarkin, V.N., Wang, X.D. \& Ren, D. (2011) A new fossil silky lacewing genus (Neuroptera: Psychopsidae) from 
the Early Cretaceous Yixian Formation of China. ZooKeys, 130, 217-228.

http://dx.doi.org/10.3897/zookeys.130.1576

Pictet-Baraban, F.J. \& Hagen, H.A. (1856) Die im Bernstein befindlichen Neuropteren der Vorwelt. In: Berendt, G.C. (Ed.), Die im Bernstein befindlichen organischen Reste der Vorwelt gesammelt, in Verbindung mit Mehreren bearbeitet und herausgegeben von Dr. Georg Carl Berendt. Band 2, Abteilung 2. Nicholaische Buchhandlung; Berlin, pp. 41-125, 4 pls.

Ponomarenko, A.G. (1984) Neuroptera from the Jurassic of eastern Asia. Paleontologicheskii Zhurnal, 1984 (3), 64-73. [in Russian]

Reed, K.M. (Ed.) 1996. Republic Centenary Issue. Featuring articles about the geology of the Republic area, the Republic Mining District, and Eocene fossil deposits. Washington Geology, 24 (2), 1-48.

Ren, D. \& Yin, J.C. (2002) A new Middle Jurassic species of Epiosmylus from Inner Mongolia, China (Neuroptera: Osmylidae). Acta Zootaxonomica Sinica, 27, 274-277. [in Chinese, English summary]

Rust, J. (1999) Biologie der Insekten aus dem ältesten Tertiär Nordeuropas. Habilitationsschrift zur Erlangung der venia legendi für das Fach Zoologie in der biologischen Fakultät der Georg-August-Universitäat Göttingen, 482 pp.

Tillyard, R.J. (1922) Mesozoic insects of Queensland. No. 9. Orthoptera, and additions to the Protorthoptera, Odonata, Hemiptera and Planipennia. Proceedings of the Linnean Society of New South Wales, 47, 447-470.

Tillyard, R.J. (1925) Two new species of silky lacewings (Family Psychopsidae, Order Neuroptera Planipennia) from Australia. Proceedings of the Linnean Society of New South Wales, 50, 387-390.

Tjeder, B. (1960) Neuroptera-Planipennia. The Lace-wings of Southern Africa. 3. Family Psychopsidae. In: Hanström, B., Brinck, P. \& Rudebeck, G. (Eds.), South African Animal Life. Results of the Lund University Expedition in 1950-1951, Vol. VI. Swedish Natural Science Research Council, Stockholm, pp. 164-209.

Wang, X.L. \& Bao, R. (2006) A taxonomic study on the genus Balmes Navás from China (Neuroptera, Psychopsidae). Acta Zootaxonomica Sinica, 31, 846-850.

Wang, Y.G., Liu, Z.Q., Ren, D. \& Shih, C.K. (2010) A new genus of Protosmylinae from the Middle Jurassic of China (Neuroptera: Osmylidae). Zootaxa, 2480, 45-53.

Wang, Y.G., Liu, Z.Q., Ren, D. \& Shih, C.K. (2011) New Middle Jurassic kempynin osmylid lacewings from China. Acta Palaeontologica Polonica, 56, 865-869.

Winterton, S.L. \& Makarkin, V.N. (2010) Phylogeny of moth lacewings and giant lacewings (Neuroptera: Ithonidae, Polystoechotidae) by using DNA sequence data, morphology, and fossils. Annals of the Entomological Society of America, 103, 511-522. http://dx.doi.org/10.1603/AN10026

Wichard, W., Gröhn, C. \& Seredszus, F. (2009) Aquatic insects in Baltic amber. Wasserinsekten im Baltischen Bernstein. Verlag Kessel, Remagen, 336 pp.

Wolfe, J.A., Gregory-Wodzicki, K.M., Molnar, P. \& Mustoe, G. (2003) Rapid uplift and then collapse in the Eocene of the Okanagan? Evidence from paleobotany. Geological Association of Canada-Mineralogical Association of Canada-Society of Economic Geologists, Joint Annual Meeting, Vancouver, Abstracts 28, 533. [CD-ROM]

Yang, Q., Makarkin, V.N., Winterton, S.L., Khramov, A.V. \& Ren, D. (2012) A remarkable new family of Jurassic insects (Neuroptera) with primitive wing venation and its phylogenetic position in Neuropterida. PLoS ONE, 7 (9), e44762. http://dx.doi.org/10.1371/journal.pone.0044762 